\title{
Where Spatial Visualization Meets Landscape Research and "Pinballology": Examples of Landscape Construction in Pinball Games
}

\author{
Dennis Edler ${ }^{1} \mathbb{D}$
}

Received: 6 February 2020 / Accepted: 2 April 2020 / Published online: 18 April 2020

(c) The Author(s) 2020

\begin{abstract}
Maps and map-like visualizations in digital games have been repeatedly addressed in research of cartography and related disciplines. For example, visualization techniques and tools used in video and computer games, including navigation and locomotion tools in VR gaming, have been analyzed and adopted to VR-based 3D cartographic modeling in recent time. A successful and diversified game which has only hardly been considered in the literature so far is pinball. Modern pinball machines are equipped with sophisticated map-like playfields (and other related components) that allow pinball players to immerse into a rapidly changing spatial story which is directed by the pinball movement. The (endless) game of skill is cognitively challenging and it sometimes even 'plays with' overloading the cognitive capacity of players by activating a multitude of multisensory (spatial) events. An overloaded communication of spatial information is apparently part of the success story of the game. The successful story of pinball also includes several characteristic themes that seem to fascinate the worldwide community of players (and retro fans). These themes, including their map-like visualizations, invite players to be involved into the rapid spatial story, and they include many 'triggers' for the individual and social construction of landscapes. These landscapes can fulfill desires for escapism. This article presents characteristic examples of successful and established modern pinball themes and discusses their potentials for landscape construction, from a social constructivist perspective.
\end{abstract}

Keywords Multimedia cartography $\cdot$ Gaming $\cdot$ Pinball $\cdot$ Landscape $\cdot$ Landscape research

\section{Raumbezogene Visualisierung trifft auf Landschaftsforschung und „Pinballology“: Beispiele der Landschaftskonstruktion in Flipperspielen}

\section{Zusammenfassung}

Karten und kartenverwandte Darstellungen in digitalen Spielen wurden bereits in der Forschung zur Kartographie und Nachbardisziplinen thematisiert. Entsprechende Analyse- und Übertragungsansätze beziehen sich bspw. jüngst auf Visualisierungstechniken und -tools, die in Video- und Computerspielen eingesetzt werden, inkl. Methoden zur Navigation und Fortbewegung im Bereich der immersiven Virtual Reality (VR). Ein erfolgreiches und vielseitiges Spiel, das bislang nur am Rande in der Fachliteratur berücksichtigt wurde, ist „Pinball“ (im deutschsprachigen Raum auch bekannt als „Flipper“). Moderne Flipperautomaten sind mit ausgefeilten kartenähnlichen Spielfeldern (und weiteren verwandten Komponenten) ausgestattet, die es den Spielern ermöglichen, in eine sich schnell verändernde räumliche ,Geschichte ' einzutauchen. Diese

Electronic supplementary material The online version of this article (https://doi.org/10.1007/s42489-020-00044-1) contains supplementary material, which is available to authorized users.

Dennis Edler

dennis.edler@rub.de

1 Geomatics/Cartography Group, Geography Department, Ruhr University Bochum, Bochum, Germany 
wird durch die Bewegung von Flipperkugeln bestimmt. Dieses (endlose) Geschicklichkeitsspiel ist kognitiv anspruchsvoll und es , lebt‘ vom provokanten Einsatz kognitiver Überladungen der Spieler, die durch eine Vielzahl multisensorischer (räumlicher) Ereignisse forciert werden. Eine überladene Kommunikation räumlicher Informationen ist augenscheinlich Teil des Erfolgskonzepts des Spiels. Die erfolgreiche Geschichte von Flipperspielen umfasst ebenfalls charakteristische Themen, die die weltweite Community der Spieler (und Retro-Fans) zu begeistern scheinen. Diese Themen, inkl. ihrer kartenverwandten Visualisierungskomponenten, laden Spieler in eine sich rasch verändernde räumliche Geschichte ein. Ebenso enthalten sie einige ,Auslöser' für die individuelle und soziale Konstruktion von Landschaften. Diese Landschaften können Wünsche nach Alltagsflucht erfüllen. Dieser Aufsatz stellt charakteristische Beispiele an erfolgreichen und etablierten (modernen) Spielthemen vor. Potenziale für Landschaftskonstruktion werden dabei aus einer sozialkonstruktivistischen Perspektive diskutiert.

\section{Introduction}

Whoever spent a night out playing a pinball game might have experienced the feeling of being immediately 'immersed' into the quickly and spontaneously changing 'story' taking place on an animated and interactive map-like pinball playfield. In the context of pinball gaming, it seems that people are captured by a multisensory spatial 'theater' which is far away from common standards of designing user-oriented media used to communicate spatial information efficiently, such as modern digital maps. Modern pinball games include map-like cartographic media, especially playfields and (animated) images. These components are the basis for evoking 'spatial stories' and triggering the individual and social construction of landscapes that are related to pinball themes.

Going through the history of modern pinball gaming, it appears that there are characteristic spatial pinball themes which seem to have attracted generations of pinball players over the decades. Based on a selection of pinball examples and map-like pinball components, this article introduces these spatial pinball themes. It indicates the possibilities of pinball design —an 'exotic' neighboring field of (game) cartography-for evoking social and individual meanings. This article binds aspects of cartography to established concepts of constructivist landscape research and "pinball-ology", a term coined by Marco Rossignoli (2011, p. 20).

\section{Cartography and Cognition}

In today's efficiency-driven society, it is of increasing importance that visualizations of geographic space deliver facts and information effectively and quickly. To meet this direction of functional cartography (see originally Robinson 1952), many research teams have invested their capacities to investigate modern forms of (cartographic) visualization based on established empirical methods. The overall objective is to derive and recommend empirically verified and robust construction rules that cope with human cognitive behavior and improve the performance of information transfer (e.g., Dickmann et al. 2017; Dong et al. 2020; Griffin and
Fabrikant 2012; Keskin et al. 2019; Kuchinke et al. 2016; Lokka et al. 2018; Roth et al. 2017; Schiewe 2019).

Thanks to developments in neighboring academic disciplines and related industries, such as gaming, informatics and (other) engineering fields, the opportunities for enhancing the visualization of geographic space are undergoing a permanently ongoing development. This leads to new variants of media that can include many new facets and features, such as high-quality sound (e.g., Berger and Bill 2019; Edler and Vetter 2019; Indans et al. 2019; Hruby 2019; LammertSiepmann et al. 2017; Schito and Fabrikant 2018), information graphics (Dunlap and Lowenthal 2016; Meier 2017; Schiewe 2017), 3D animation (Edler et al. 2018a; Kersten et al. 2018; Lovett et al. 2015), and gamified interaction techniques (Ahlqvist 2011; Kapenekakis and Chorianopoulos 2017; Lütjens et al. 2019) — to name just a few examples that are intensively discussed in recent international literature of cartography and related disciplines.

In addition, network opportunities provided by the Internet allow professionals and 'home brewers' to exchange and discuss their ideas and approaches. The 'add-on components' that form the present and future of spatial visualization arrive via different information sources than it used to be before. Accordingly, present and future research that addresses human cognitive processing and efficient communication of spatial information is confronted with a myriad of visualization components and combination possibilities (Clarke et al. 2019).

\section{Spatial Games as Social Constructs}

Following this direction of a cognitive cartography driven by efficiency and technology, it seems a bit odd to think that there has been a successful market for map-like visualization products that aim to 'play with' the user's cognitive overload and technology established in the last century. The nature of games, however, allows to put the concept of a highly functional and timely cartography aside which aims to find solutions for the most accurate and efficient (digital) transfer of spatial information. In the context of map use 
in games, user orientation is not focused on a reduction of unnecessary visual or auditory stimuli. The main objective is high user entertainment within a spatiotemporal framework. To achieve this, it is the task of game creators to find combinations of (multisensory) stimuli that catch the user's interest and attention-even if a high amount of cognitive resources is required to process the combined stimuli (see also Ginns 2006).

Playing games makes it possible to escape from the everyday routine (Fontaine 2017, p. 257; Calleja 2010; Muriel and Crawford 2018). Games arise from the cognitive ability to create-or to pretend - an imaginary spatial reality and they fulfill the human desires for play in these imaginary landscapes (see also Adams 2014, p. 1).

In the context of games, the concept of landscape is not reduced to material items that shape an 'objective' physical arrangement where spatial events can take place. Even if this material spatial setting might appear as 'objective' to the single player or group of players, a certain level of 'subjectivity' imposed by the game creator(s) is an inevitable accompaniment of the landscape representation. An unbiased game creation can be excluded by the nature of the task. This is comparable to the creation of thematic maps which are semantically controlled and filtered ("generalized") by cartographers (Zook et al. 2017, p. 543; Morrison 1974). This 'producer-biased' material game setting allows people - in their role as players (consumers) — to shape out an individual and social construct of the experienced landscape including the game-based story within it. Such physical arrangements with spatiotemporal changes are material (including virtual) media in games that serve as 'transmitters' for the individual and social construction of imaginary (game-based) landscapes.

The construction of landscapes in games is an example of socially and culturally mediated knowledge. It can be compared to the construction of landscapes in other mass media of popular culture, such as movies (see Cosgrove 1998; Escher and Zimmermann 2001; Kühne 2012; Harvey 1990). Like in movies (Lukinbeal 2005), the social construction of landscapes in games relies primarily on perception and vision. In addition, there is a distinct component of interactive intervention in games (see also Bendrups 2004, p. 101) which causes a physical transformation of the landscape and spatial storyline. This intervention component can usually not be found in the closed (narrative) sequence of a movie (see also Juul 2005).

In the literature of social constructivist landscape research, it has repeatedly been emphasized that the production and consumption of mass media are driving forces for the construction of social knowledge in modern and postmodern societies (Burgess and Gold 1985; Kühne and Schönwald 2015; Zimmermann 2019). This media-based construction of landscape, however, is not unidirectional and restricted to the component of social construction, as (spatial) media also put across physical foundations of landscapes (Dear 2000; Kühne and Schönwald 2015).

Hence, it can be assumed that playing a game causes the formation of a cognitive representation of the physical spatial arrangement of a game landscape (cognitive map), including common metrics of positivistic approaches, such as object locations, distances between them and angles (see Dickmann et al. 2019; Tversky 1981; Okabayashi and Glynn 1984; Postma and De Haan 1996; Stevens and Coupe 1978). Moreover, it allows individuals and groups (of society) to socially construct an imaginary landscape which is based on the physical spatial setting and is specified by social and cultural meanings of society. In addition, the socially constructed landscapes satisfy a desire for escapism (c.f. Fontaine 2017) by mentally replacing the 'everyday system' (including place and external obligations) by an unaffected and carefree 'parallel universe' where the player of the game can make things happen.

\section{Spatial Games and Cartography}

As games are complex systems where spatial events occur in physically and socially constructed landscapes, it is not surprising that geographers and cartographers have repeatedly dealt with the topic of 'cartography and gaming' (e.g., Edler et al. 2018b; Garfield 2012; MacEachren 2004, p. 155; Dormann et al. 2006; Taylor and Lauriault 2007). In the literature of multimedia cartography and "cybercartography" (Brauen and Taylor 2008; Caquard et al. 2008), most articles addressed the technical side of games and the engineering components used to communicate a spatial story in the games (see Cartwright 2007; Lauriault and Taylor 2014; Taylor 2006).

Especially, video and computer games were identified as valuable sources to analyze and improve animation and interaction techniques in multimedia cartography (Coulton et al. 2017; Edler and Dickmann 2016, 2017; Ahlqvist 2011; Lammes 2008). The discussions on the impact of games on cartographic visualization are currently influenced by rising opportunities to create environments in (immersive) virtual reality (VR) (e.g., Boletsis 2017; Büyüksalih et al. 2020; Hruby et al. 2019; Edler et al. 2019a; Tschirschwitz et al. 2019; Vetter 2019; Walmsley and Kersten 2020; Zhao et al. 2019) and augmented reality (AR) (e.g., Çöltekin et al. 2019; de Almeida Pereira et al. 2017; Keil et al. 2020; Lindner et al. 2019; Werner 2019).

Discussions on immersive 3D environments are not only limited to questions addressing an improved visualization and use, but also they have already been suggested as valuable present and future tools for different application scenarios, such as landscape and urban planning (e.g., Jamei 
et al. 2017; Ma et al. 2020; Salter et al. 2009; Virtanen et al. 2015). The social construction of landscapes in video and computer games, which are based on modern visualization techniques, has only hardly been addressed so far (Edler et al. 2018c; Fontaine 2017; Kühne 2019).

Aside from video and computer games, the gaming industry has also developed other gaming formats inviting the players to 'spatial stories' that take place on elaborately designed map-like visualizations. The long and ongoing history of pinball (arcade) gaming shows that many people around the globe seem to be fascinated by the highly interactive and cognitively challenging (openended) games which take place in sophisticated game landscapes.

\section{Pinball Games in Brief}

Ancestors of modern pinball machines, such as the French game "Bagatelle", already existed in the late eighteenth century. The rise of a serious pinball industry began in the late 1920s/early 1930s. In the 1950s, many (electromechanical) pinball machines were established with various themes. Even if video and computer gaming took over the lead role in the spotlight of modern gaming in the 1990s, new pinball machines are still manufactured today (Burgun 2013, p. 73). Moreover, pinball machines from across the history have been collected and restored by fans of 'retro gamers', which underlines the present interest of people in pinball gaming (Fowlks 2019; Barton 2017; Rossignoli and McGuiness 2007).

The primary aim of pinball games is to score as many points as possible and to play as long as possible"score equals skill" (Lanzinger 2019, p. 105). Success in the game requires that one or several metallic balls (also referred to as "silver ball", see Flower and Kurtz 1988) are kept in a (map-like) playfield. The playfield is usually arranged in an inclined position and lies inside a glass-covered cabinet. The player cannot manipulate the dynamic path of the ball by touching objects on the playfield. Player interaction concentrates on redirecting the ball by controlling the limited opportunities of two small (electro)mechanical levers that are positioned at the bottom of the playfield-commonly called "flippers", after the invention of the pinball machine "Humpty Dumpty" in the 1940s (designed by Harry Mabs and published by Gottlieb, see also Rossignoli 2011, p. 37). Depending on the velocity and direction of the balls, several objects on the field are hit, such as bumbers (cylindrical or rectangular objects applying force to the metallic ball), spinners (rotating objects), ramps (linear sections with a raised gradient) or other (more thematic) targets. These physical variables cause counteractions which can jeopardize the aim of holding the ball in the game. Between the two paddles is a drain, and the game is over as soon as the (last) ball has fallen into this drain.

\section{Examples of Pinball Landscapes}

Since the 1930s, more than 3000 pinball games (excl. pinball video, computer and mobile games) have been created by about 180 pinball manufacturers from ten different countries. Most pinballs (about $80 \%$ ) have been built in the USA (Rossignoli 2011, p. 300-301). Accordingly, the spatial stories that can be experienced and constructed through pinball games are massively influenced by the culture, history and geography of the USA.

Thanks to the eager work of a few book authors (especially Bueschel and Gronowski 1993; Ciuffo 2014; Eiden and Lukas 1992; Flower and Kurtz 1988; Kurtz 1994; Rossignoli 2003, 2011; Rossignoli and McGuiness 2007; Shalhoub 2002, 2004, 2005, 2012; Sharpe 1977; Zsolnay 1994) and many web users who compiled informative online databases with texts and images from all over the world (e.g., "The Internet Pinball Machine Database"-https:// www.ipdb.org and "The Internet Pinball Database"-https ://pinside.com), the history of pinball gaming as well as details of the different pinball machines are well documented and publicly available. These sources provide a basis for an investigation of existing pinball machines, with a specific focus on their map-like playfields and backglasses, i.e., the components of the machine which are most fixated by the player during the game (see Fig. 1).

The map-like playfield lies behind a glass-covered cabinet. The backglass is a vertical panel installed on the front end of the backbox. Below the backglass image lies a dot matrix display with additional graphical animation. This additional animated component can be found in many pinballs from the 1990s onwards (first pinball machine with a dot matrix display: "Checkpoint", released by Data East in 1991). A similar sketch of the major pinball components is provided by Rossignoli (2011, p. 22).

\subsection{Representations of Existing Places}

Having a closer look at various pinballs, it becomes obvious that existing places have been selected as pinball themes over the decades, especially US cities, and also other places in America (e.g., Monterrey, Panama, Tampico) and in other parts of the world (e.g., Hong Kong, Naples, Shanghai), were 'translated' into pinball machines. The names of the pinballs also correspond to the geographic names of existing places (see Table 1 in 


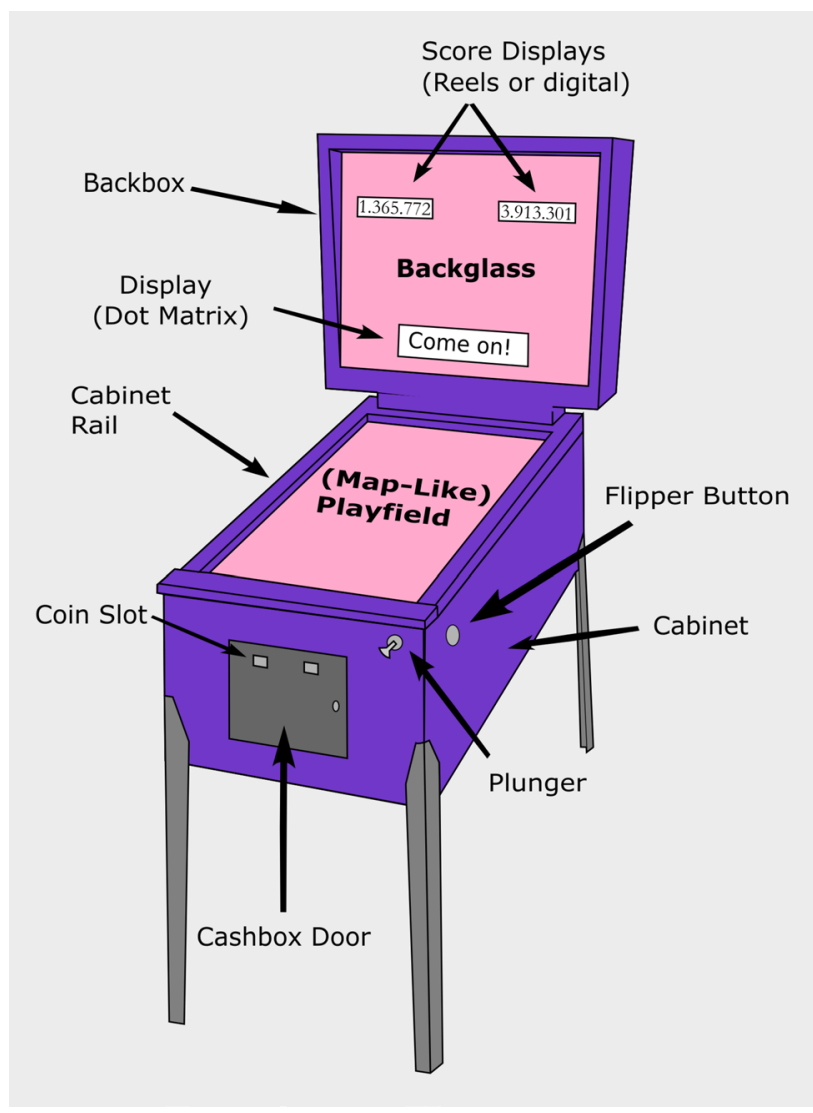

Fig. 1 The main components of a pinball machine
ESM). One example selected from many possibilities is illustrated in Fig. 2. It includes images of the pinball "Central Park" [released by Gottlieb (1966)]. The images of the backglass (left) and the playfield (right) indicate that the park in Manhattan is represented with generalized and simplified images showing relaxed visitors in different situations. The playfield can be compared to a topogram. It includes illustrations of different spatial sections with different situations of enjoyment in the park, such as having a picnic on a bench, playing on the grass, going for a walk, having a conversation, flirting or being amused by animals. The color composition dominated by yellow and green backs up a friendly urban summer atmosphere. Success in the game (scoring points with the metallic ball) is bound to illuminated feedback on the playfield (depending on the hits of the ball) and additional sound feedback from a 'park character' which is included in the (3D animated) backglass (a monkey ringing a bell, see Fig. 2).

As in many other examples of pinball themes that simulate a situation of existing places (see Table 1 in ESM), the players are confronted with a set of graphical-sometimes also multisensory-stimuli that activate processes of individual interpretation and construction of landscapes. This can include cultural, social and historical aspects. The graphical 'triggers' in the game are, for instance, the represented human characters (including clothing, habits, gestures), animals and vegetation, and object representations of the 'material' landscape, such as buildings, vehicles and instruments.
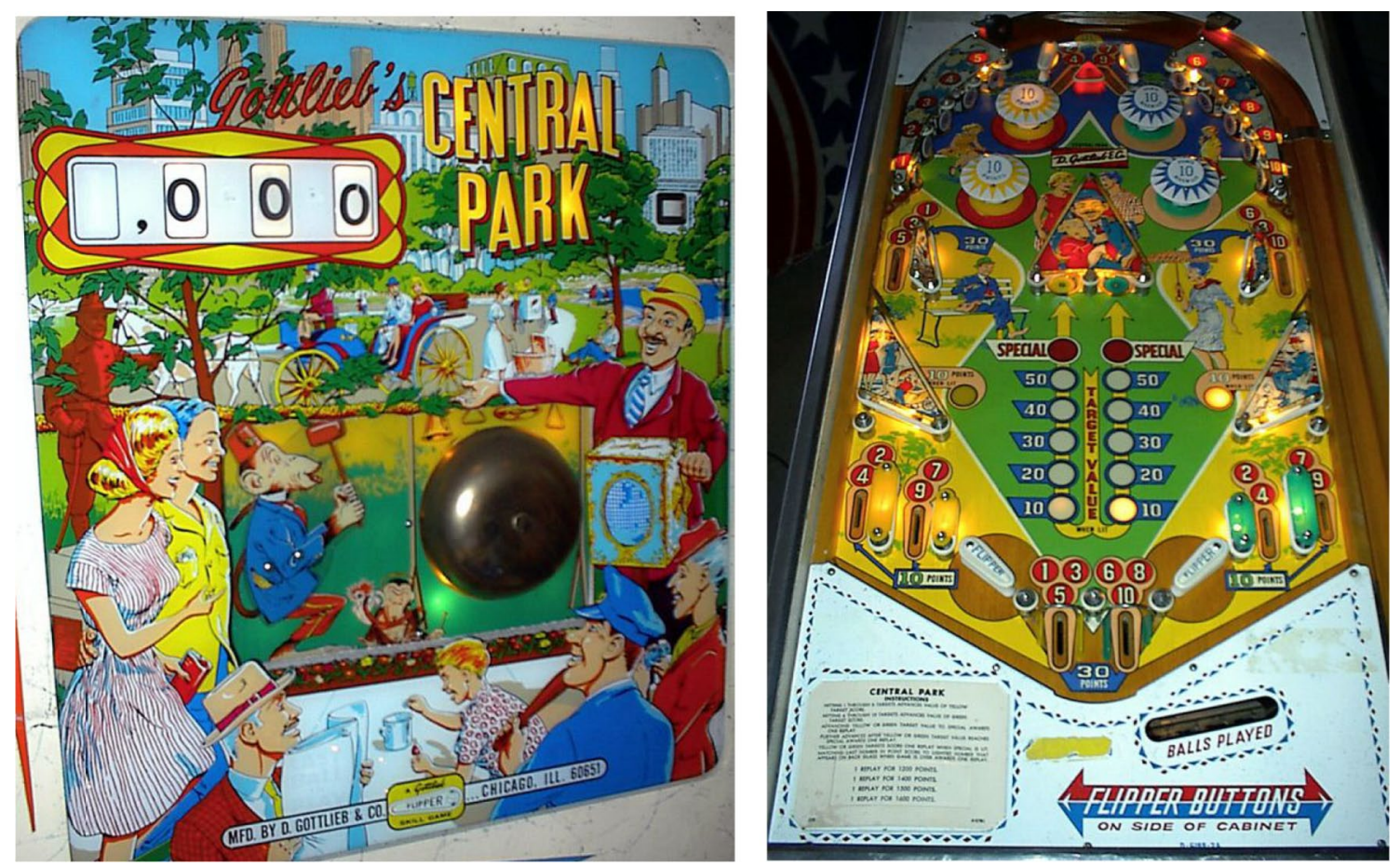

Fig. 2 Central Park (1966) — an urban summer landscape in New York City @ Ken in Texas (via https://www.pinballrebel.com) 
The fact that the represented objects are bound to an existing place 'provokes' spatial recognition and creates a sense of identification (see also Fontaine 2017, p. 226). The visual landscape presentation in the "Central Park" pinball invites the players to feel immersed into a game-based simulation of a positive (urban) summer setting - a virtual reality that is related to stereotypical landscape features.

Stereotypical landscapes are characterized by the "relative universality of their esthetic standards" and the simplicity of their symbolism (Kühne 2018a, p. 83). They emerge from abstraction and they are often shaped out by secondary sources (common media of everyday life), and not necessarily by the direct experience of physical landscapes (Kühne 2015). Together with internalized and emotionally charged landscape patterns of childhood and adolescents ("normative home landscape"), stereotypical patterns influence human perception and evaluation of landscapes at the individual level. Both the normative home landscape and stereotypical landscape are stored in human memory and serve as 'normative filters' in the social construction of landscapes (Kühne 2018a, pp. 83/84). The esthetic evaluation of a game landscape, of course, may differ between the individual players, as its emerging individual social construct is further influenced by (multisensory) experiences the players have made in similar landscapes so far (see Fontaine 2017, pp. 52-54).

In addition, the game-based individual and social landscape construction goes along with the player's 'cognitive voyage' from the everyday environment to a different place. This form of escapism allows to feel involved in a different place whose details can be physically through interaction with flippers and balls-and, especially, mentally 'co-designed' by the game players. The desire for escapism through media, such as games (Fontaine 2017; see also Evans 2001), is not restricted to simulations of 'real' topographies (as in the example of "Central Park"). Many other pinball themes show that stereotypical landscape representations, i.e., simplified landscape constructs shared by societies and cultural communities (see also Kühne 2018a), attract people to get involved. It does not seem to matter if a clear reference to an existing and named geographical location is missing.

\subsection{Representations of Stereotypical Landscapes}

Pinball games compiled in Table 2 (see ESM) indicate the multitude of stereotypical landscapes which have been offered by pinball designers and manufacturers to their customers. Like the Central Park example (see Fig. 2), the focus is on graphical (or audiovisual) symbols that form a generalized and simplified representation of idealized spatial settings. These 'model landscapes' may lead to individual landscape constructions. However, as they 'play' with landscape stereotypes, a common ground for similarities between individual constructions and interpretations is established. The repetitive use of similar stereotypical landscapes (e.g., sunset sceneries, underwater landscapes, and representations of paradise, see Table 2 in ESM) underlines the success behind this approach in pinball history.

While stereotypical landscapes are often associated with signifiers of pre-industrial times (Kühne 2017; Micheel 2012), stereotypical pinball landscapes often include signifiers of urban life. Urban landscapes convey deep meanings to their inhabitants and tourists, and they are often given a higher economic, social and cultural relevance than rural landscapes. Traditionally, towns and cities are however negatively connoted-“'A beautiful and delightful city environment is an oddity, some would say an impossibility" (Lynch 1960 , p. 2). They are the 'departure points' for escaping to the 'romantically charged' and 'unspoiled' countryside, especially in times of industrialization (Howard 2011, p. 207; Whyte 2002, p. 174).

In landscape theory on the esthetic construction of landscapes, urban landscape elements are qualified as disturbing. In this context, they are also discussed as non-stereotypical items in the landscape construction (Linke 2019, p. 445). However, due to their high complexity, urban landscape elements cause attraction, which is associated with a positive esthetic evaluation. Contrariness, hybridity and mixed sensations are known to be additional positive impacts on landscape esthetics (Liessmann 2009, pp. 33-34; Kühne and Schönwald 2015; Linke 2019). According to Kent (2018, p. 308), "human landscapes", in contrast to "areas of wilderness", may also "convey a sense of vitality, order and civilization through its symbols". Moreover, processes of postindustrialization (in countries of North America, Western Europe and Japan) have led to a new esthetic assessment of physical urban landscapes (Kühne 2018b, pp. 50-51; Jenal 2019; Schönwald 2015). Industrial urbanity is idealized, and urban components of industrial times are considered as "wild nature" (Kühne 2019, p. 44).

The urbanity of the twentieth century, the time when pinball became electrified, coin operated and popular (Shalhoub 2002), was a topic which was repeatedly taken up for pinball machines (see Table 2 in ESM). Towns and cities deliver many themes of interest for the people that influenced pinball landscapes. Innovations in cities making urban life faster and more dynamic are regularly addressed in pinball games with urban themes, on different scales. To put emphasis on such aspects, the game creators only have a limited space for a mainly graphical (but also audiovisual) map-like representations in a pinball game [concentrated on playfield and backglass (image), see Fig. 1]. Examples of urban pinball landscapes — on different scales—can be found in many pinball machines, such as "Subway" $(1934,1966)$, "Subway Special” (1934), "Airport" (1939, 1969), "Cross 


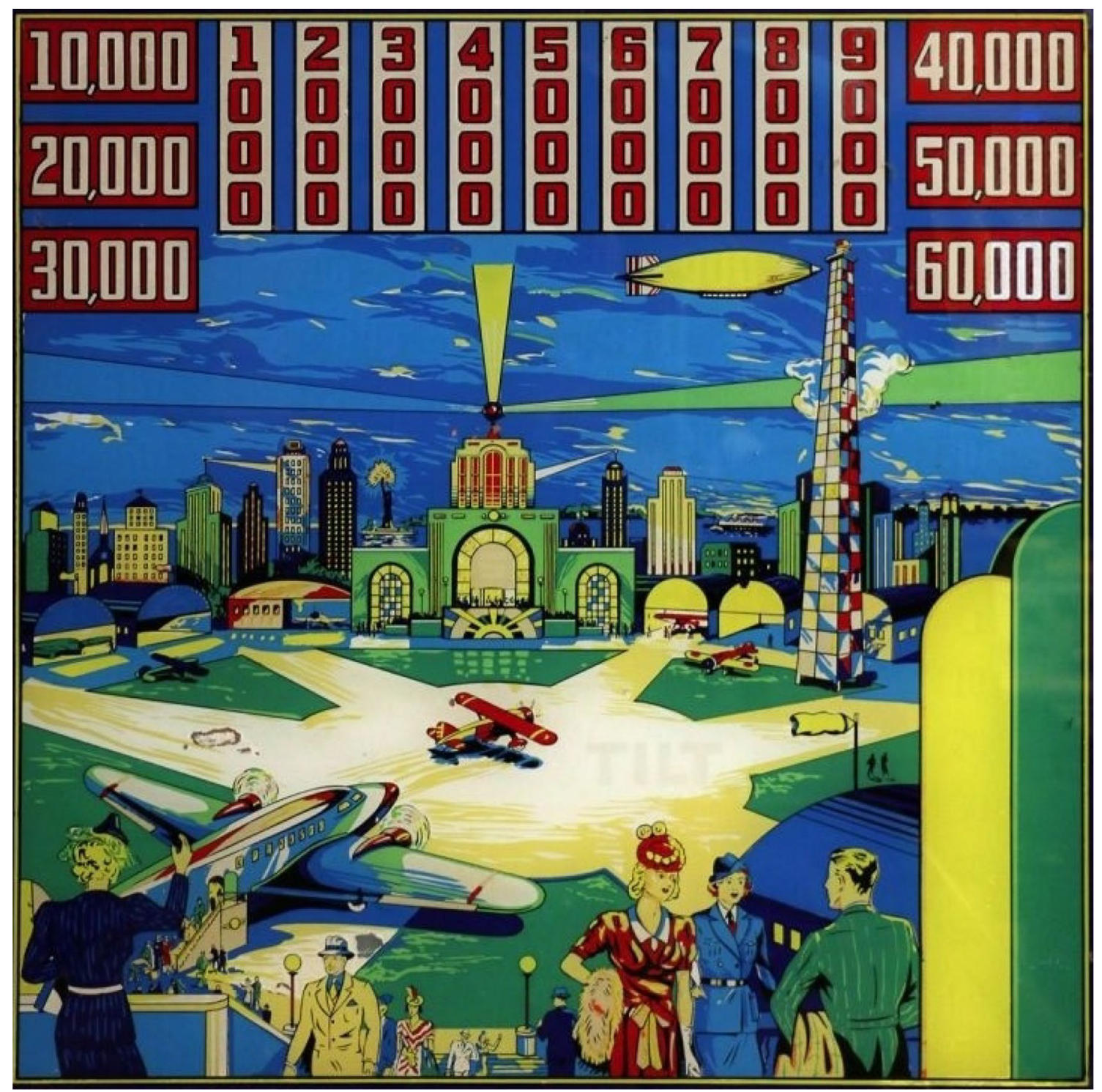

Fig. 3 Airport (1939)—appreciation of industrial and technological innovations in urban landscapes

Town" (1966), "Highways" (1961), "Tramway" (1974), "Skyscraper" (1934) and "Sky Line" (1965).

The pinball "Airport" (released by "Genco" in 1939), for example, comprises a graphical representation of the "LaGuardia Airport" (LGA) in Queens, New York City (see the backglass image in Fig. 3). The pinball machine was released in the same year the new airport was opened. The airport, at that time, was an (urban) signifier of the public fascination for air travel. It was a new aviation hub with modern aircrafts representing the 'pinnacle' of commercial aviation in the USA. Moreover, it stood for the latest technological innovations of the time (Stoff 2008).

The pinball theme combines the wish for travelling-going along with fulfilling a desire for escapism (leaving the city and urban life)-with appreciation for technological innovations. The positive attitude toward industrial progress is mirrored by the backglass image of the "Airport" pinball. It is filled with industrial and constructional objects, such as aircrafts and distinct buildings (skyscrapers, control tower and the airport terminal). The buildings are brightly illuminated, and the bright colors are rich in contrast with the 'cold' and 'distant' blue tones of the night sky (aspect of nature) in the background. Aviation and aircrafts are given specific emphasis, and the sound of aircrafts on the runway is imitated when the (metallic) pinball rolls over the (wooden and groomed) playfield. This approach of an audiovisual redundancy seems to be an early (1930s) example of an audiovisual map which includes a simulation of an audiorealistic urban or industrial soundscape (c.f. Edler et al. 2019b; Laakso 
and Sarjakoski 2010; Schafer 1977), without computer animation (c.f. Krygier 1994; Müller and Laurini 1997), but with a rolling metallic ball on an inclined wooden playfield. High scores in this game can especially be achieved if the ball hits targets located 'high' in a graphical representation of the sky (playfield).

The example of the "Airport" pinball (1939), and other pinball machines mentioned above, indicates that the designers of urban pinball landscapes address the dynamics of a vivid and vibrant urban life. Industrial innovations, such as motorized vehicles and modes of transportation, are highlighted in the simplified urban sceneries of pinball graphics. The dynamics and motion of urban life are emphasized and intensified by the rapidly moving ball in the game. This can be intensified by using positional illuminations and sound effects. It seems that a 'stereotypical urban pinball landscape' seems to be composed of representations of urban industrialization. Players apparently enjoy involvement in a rapidly moving urban environment. The concept and context of a dynamic and fast-moving game may lead to a concentration on dynamic aspects of life, which appears to have a strong impact on the social construction and esthetic evaluation of a game-based landscape.

\subsection{Representations of Game Landscapes in the Pinball Game}

Dynamic urban life may also 'end up' in specific and much more 'ego-oriented' places (on a local scale) which are associated with gambling, such as horse racetracks, motor racetracks, stadiums, pubs, bars, casinos and amusement arcades. Horse racing, motor racing, darts, pool table, dice games, roulette, jackpot games, poker and other card games obviously attract the worldwide community of pinball players. This also applies to themes referring to sports (see examples of pinball themes in Table 3 in ESM). Such themes take up the ideas of competition, quest and fortune, as the pinball game itself does. These ideas are accompanied by fast changes and an uncertain ending of two extremes (either win or lose). They establish an ego-oriented and attractive spatial scenery of risk which also addresses escapism (see further Nordheim and Antoni 2013, p. 95; Fontaine 2017, p. 202). The degrees of self-involvement and 'local concentration' on a 'large-scale' game landscape seems to be much higher if the player faces a doubled and interwoven game success (game of the pinball theme within the pinball game).

Pinball themes and emerging game landscapes on pinball gaming (see Table 4 in ESM) even suggest a meta-level of the game itself. They might even increase the levels of involvement and local concentrations, as the game itself is fully concentrated on the processes of pinball. A pinball game in a pinball game may also serve to highlight pinball history and production, (technical) characteristics of pinballs or to exaggerate and even parody the game itself (meta pinball themes).

\subsection{Representations of Landscapes Known from Other Media of Popular Culture}

Other "potent hotbeds of escapism" (Evans 2001, p. 109) are arts and the media. Many examples of pinball games exist whose themes pick up the spatial setting of popular culture, such as literary fiction, comics, movies, cartoons, sitcoms and magazines (see Table 5 in ESM). Interactive items in the pinball playfield are adopted from the fictional setting and serve as signifiers of intermediality. The 'imaginative landscapes' of popular culture-also referred to as "diegetic world[s]" (Wolf 2014, p. 125)—are familiar to pinball players. They experienced them before as spectators, without being a 'physical part' of these landscapes. The landscapes of popular culture (sometimes created by 'escapists' themselves), as well as the characters, habits and roles are familiar to the players. Thus, the social constructs that have already emerged of these landscapes through interaction with the original media are subject to pre-defined accentuations. They already reflect social and cultural impacts on society and show the interpretation of the media creators. They might also address stereotypical landscape representations (e.g., Indiana Jones and James Bond).

The translation of spatial settings and stories known from popular culture into pinball games show the wish to be part of this construct in a different scenario. In terms of pinball interpretations (and this differs from other games, such as board or video games), the pinball characteristics of velocity, spontaneity and uncertainty are emphasized. So, it is not surprising that fictional stories dealing with action, (supernatural) power, crime, pursuit, magic, mystery and horror are especially taken up in pinballs, such as "Batman" (1991, 1995, 2016), "Ghostbusters" (2016), "Frankenstein" (1994), "James Bond" (1980), "A Nightmare on Elm Street" (1994) and "Indiana Jones" (1993, 2008) (for more examples, see Table 5 in ESM). These pinballs are often designed with dark colors to simulate an atmosphere of danger and uncertainty, which also corresponds to common approaches of video and computer gaming (see also Fontaine 2017, p. 219).

In the individual social construction of these themes, the peculiarities of the pinball game likely stress the abovementioned aspects of the fictional stories. In this context, the open-endedness of the game puts the player into a hopeless situation and struggle for survival. It seems to be an attraction to 'fight against' the hopeless ending in a depressing atmosphere where pinball items turn into enemies, within a 
simulated 'sheltered space' of playing a game with 'physical invulnerability'.

Apart from such examples of pinball themes communicating dangerous landscape impressions adopted from popular culture, other pinball examples support the construction of different landscapes. They take up aspects of comedy landscapes [e.g., "The Simpsons" (1990), "The Flintstones" (1994) or "Family Guy" (2007)], fantasy worlds and fairylands [e.g., "Peter Pan" (1955), "Cinderella" (1948), "Three Musketeers" (1949), "Super Mario Bros." (1992) or "Shrek" (2008)]. Some other examples provide impressions of sexually connoted 'lustful landscapes'. Some pinballs exist that pick up specific ideas of the "sexual escapist" Hugh Hefner (Evans 2001, p. 138), see for, e.g., "Playboy" (1967, 1978), "Playboy 35th Anniversary" (1989) and "Playmates" (1968).

In addition, pinball themes address two other topics that deal with specific categories of popular culture. These topics are music and space.

\subsubsection{Pinball Rock Concerts}

Pinball themes concerning music were pushed forward by technical innovations, especially by possibilities of integrating sound features. Electronically induced feedback sounds (e.g., falling into a scoring hole) were already parts of pinball machines in the 1930s. The integration of spoken feedback (voice recordings accompanying the progress of the game) is associated with "Gorgar" [released by Williams (1979)], the world's first "talking machine" (Rossignoli 2011, p. 93). Another famous pinball machine associated with talking — and even taunting—is "Funhouse" [released by Williams (1990); see also Rossignoli 2011, pp. 163/164; Shalhoub 2012, p. 128].

Sound animations in pinball games, like many visual animations as well, have the purpose of accompanying the rapidly changing position of the ball and to stress the (spatial) game story. Of course, sound is also used to intensify the theme and to create an atmosphere. It can also transport a new (non-visible) dimension into the space of the game (see also Edler and Kühne 2019; for thoughts on landscape construction based on audiovisual cartographic media). In some difficult playing situations, it is also used to disturb, which produces an intentional additional cognitive challenge for the player.

Apart from this 'multisensory pinball theater', sound can be also part of pinball themes. Sound-related themes are usually linked to music. Music-related pinball themes usually refer to rock music. Elvis Presley, who had several highlights of his career in Las Vegas, binds rock music to gambling and games. As rock music is commonly associated with a powerful and fast genre, the velocity and dynamics of the game match rock music and pinball together. The playfield can represent a stage of a rock concert [see "Heavy Metal Meltdown" (1987)] or illustrate the stories of famous rock bands or artists: "Kiss" $(1979,2015)$, "Rolling Stones" (1980, 2011), "Iron Maiden" (1981, 2018), “Guns N' Roses (1994), "The Who" (1994), "AC/DC" (2012), "Metallica" (2013), "Aerosmith" (2017) and "The Beatles" (2018).

The 'artistic landscape' created by these bands are transported through the pinball game, with a high level of sound involvement, especially music. The fictional space in the pinball game is strongly influenced by interpretations and creations of the artists. This also includes the band history (and as their origin) and conventions in the rock genre (incl. heavy metal), such as the estimation of industrial goods (see AC/DC, Fig. 4) or concepts of death and darkness. Musical landscape impressions are also suggested by the lyrics and songs by the rock artists, for, e.g., "Paradise City", "Welcome to the Jungle" and "Garden of Eden" in the pinball machine "Guns N' Roses" (released by Data East in 1994) or "Heartbreak Hotel", "Jailhouse Rock" and "Aloha from Hawaii" in "Elvis" [released by Stern (2004)]. Like in the examples of other fictional settings known in popular culture (see Sect. 6.4), these peculiarities established by the rock bands (in this case) guide and manipulate the individual and
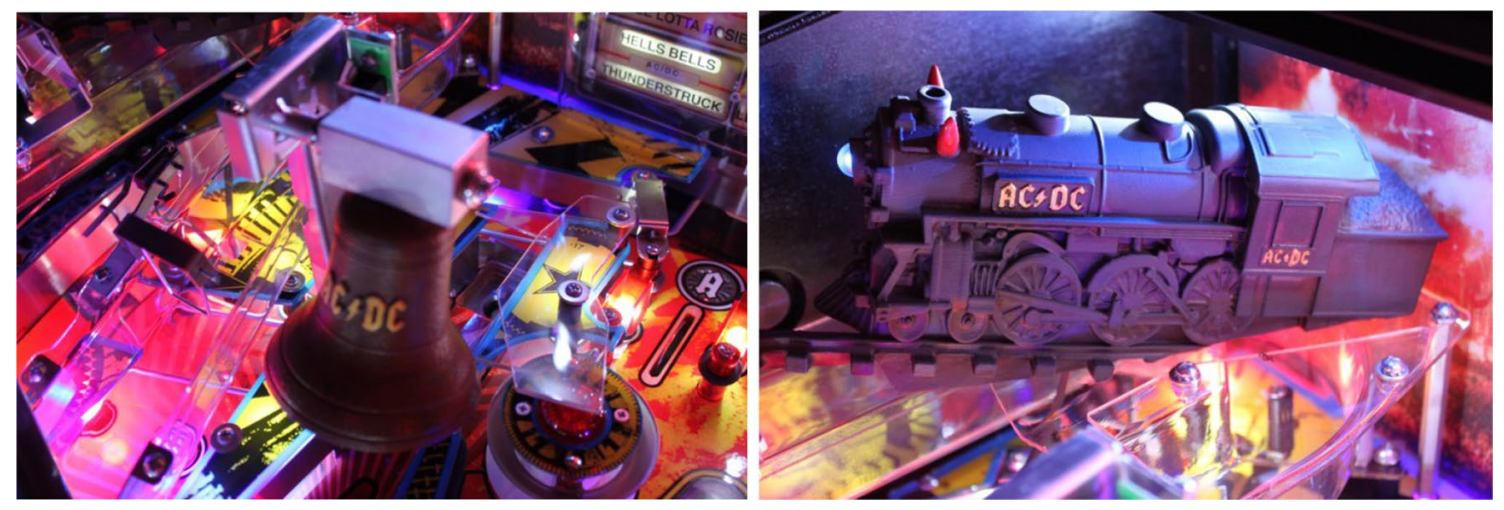

Fig. 4 Industrial symbology associated with AC/DC @ Ken in Texas (via https://www.pinballrebel.com) 
social construction of a landscape. Interpretations may have a strong impact on the social evaluation of addressed topics.

The playfield includes several physical items that appeared in famous rock songs and stage shows by AC/DC, such as "Hells Bells" and "Rock 'n' Roll Train". The spatial story in the pinball games has a high involvement of sound, especially music. The social construction of musical landscapes is influenced by the artists, including music, concerts, and their public life and values.

\subsubsection{Pinballs of Outer Space}

Pinball themes dealing with space allow their players to escape into familiar and unknown spheres of the universe. Many examples of pinball machines exist that address 'landscapes in space' (see Table 6 in ESM). Space themes are particularly associated with the 1950s and 1960s when the 'space race' was a global phenomenon (Flower and Kurtz 1988). Again (see Sect. 6.4), such pinball landscapes can take up objects established in popular fiction, such as "Star Trek" (1971, 1979, 2013), "Star Wars" (1987, 1992, 2017), "Flash Gordon" (1981) and "Stargate" (1995). When playing these pinball games, a cognitive collage of the fictional landscape in space exists and serves as a 'spatial filter' to understand the storyline experienced in the game. Players who know the science-fiction television series "Star Trek" are familiar with the Star Trek Universe and know specific objects of this universe, such as the star ship "USS Enterprise" and its missions (see Fig. 5). As discussed in the previous chapter, social conventions of this fictional world are taken up in the individual and social construction of a landscape transported through a pinball game.

The playfield represents the fiction Star Trek universe. It includes several objects known from the widely known TV series of the 1960s, such as a 3D miniature of the "USS Enterprise" (to the right). The representation of space is filtered through the universe presented in the series.

When playing pinballs with space themes, people might have similar imaginations and concepts of the universe in mind, as they are offered by various media. However, the degree of individuality in the construction of 'landscapes of outer space' as well as the level of fulfilling escapism is certainly much higher if the space theme is not within the frame of a specific and famous contribution to popular culture, such as Star Trek.

The high game speed and the uncertainty of game success correspond to the idea of fast motion in an unfamiliar environment in space. The often-used mixture of dark and shiny color matches the imaginations people might have in mind from watching the universe. Sound features

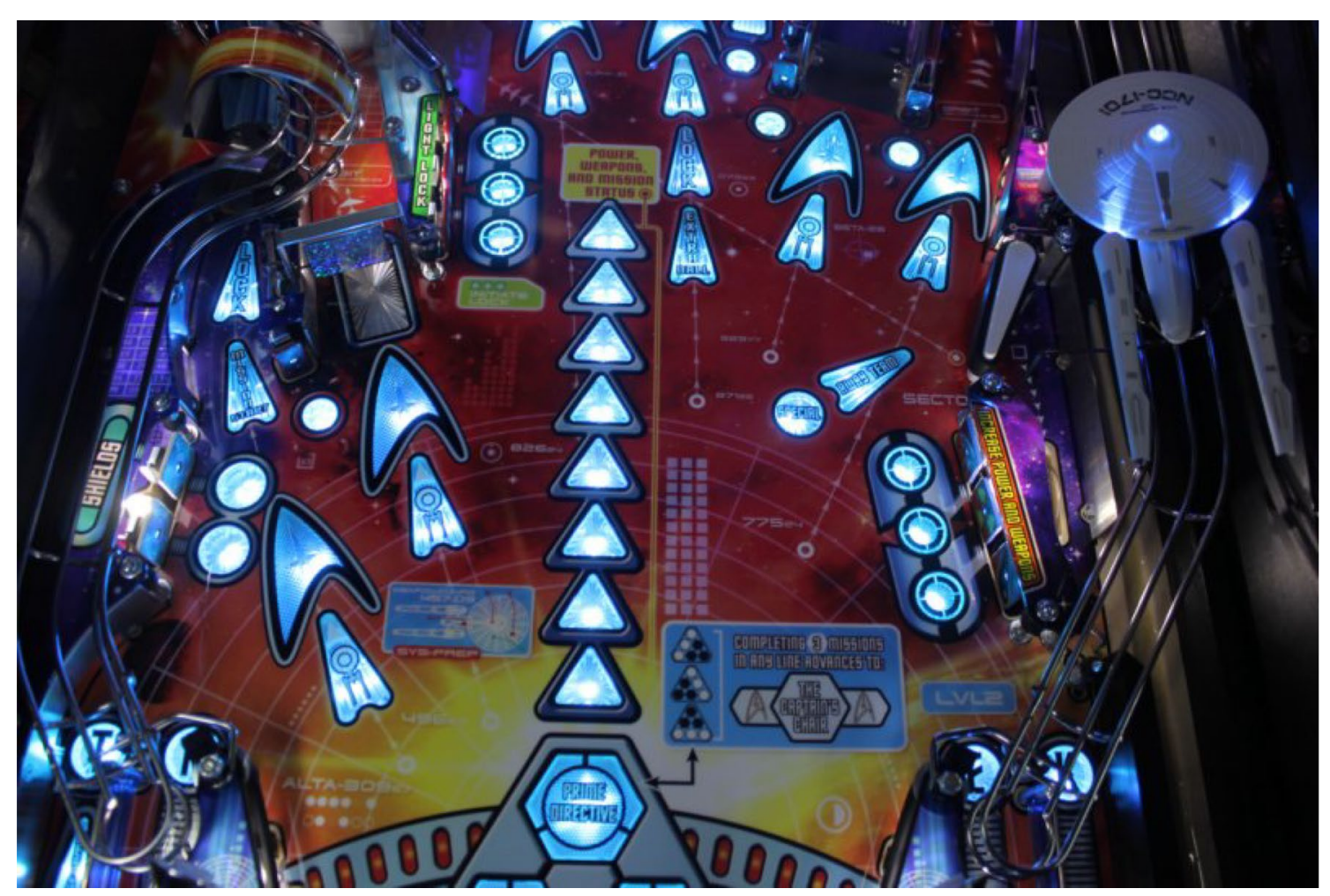

Fig. 5 A pinball representation of the universe in Star Trek (Limited Edition, released by Stern in 2013) @ Ken in Texas (via https://www.pinba llrebel.com) 
associated with space, such as astronauts sending spoken messages to Earth or synthesizer sounds, are used to underline the atmosphere.

\section{Summary}

The examples discussed in this article indicate the versatility of the pinball game for the construction of landscapes. Although the history of pinball shows a rapid development of the games (including various technical innovations and early approaches to a gamified 2D and 3D visualization and communication of a map-like 'spatial story'), the game has only hardly been considered in the research of visualization disciplines. Against conventions of a functional cartography, the map-like visualizations in a pinball game (playfield with various interactive objects, and other fixated images, such as the image of the backglass) are arranged and designed to avoid cognitive simplicity within a fast and spontaneous game. The multisensory endless game is intended to "play with' the cognitive overload of the player(s).

To communicate a spatial story, pinball creators make use of elaborate graphics-sometimes classified as "pinball art" (Rossignoli 2011, pp. 165-186; see also Ciuffo 2014). These graphics are filled with details to be discovered. They enrich the spatial story and their individual interpretations. A dominant variable to create atmosphere is color. As indicated in the examples discussed, color can help to establish a friendly (Fig. 2) and dynamic (Fig. 4, 5) as well as risky atmosphere (Fig. 5), and color contrasts can highlight certain (spatial) objects of interests (Fig. 3). The rapidly changing 'hot spot' of the game-depending on the position of the silver ball-is also accompanied by illuminations and sound effects. Although empirical evidence is still lacking, these features may influence the viewing behavior of the player, which would correlate with the player's cognitive processing. If so, they would then again serve as design elements to distract the player-even experienced 'pinball wizards'and increase the level of difficulty. It is obvious that creators of (map-like) media in pinballs assign more importance to an entertaining presentation and creative design and not primarily to the straight communication of spatial information (c.f. Kent 2013, p. 43). Cartography, especially those cartographic approaches which are given a gamified communication concept (e.g., Gemma 2013; Martella et al. 2015), could receive new impulses from the highly charged-but at the same time, a century-long successful-pinball designs.

The multisensory design and physical arrangement of the pinball playfield and other fixated images within the game (such as backglass images and additional animated displays) have an impact on the creation of a cognitive map of the (spatial) game itself. To achieve successful results in the fast (endless) game, the players need to know where to find which targets and which events they trigger. Going beyond this (positivistic) information layer in spatial memory (what can be found where?), the game includes various triggers and signifiers for the individual and social construction of landscapes. The design and arrangement of map-like pinball components, such as material (electromechanical) objects, graphics and (animated) audiovisual effects, are key elements that influence landscape construction. These elements are related to the pinball theme and unavoidably influenced by the interpretation of the pinball designer.

It is suggested in Sect. 6 that pinball games can include stereotypical landscape features of postmodern and postindustrial societies. These features invite players to escape into 'existing' and idealized landscapes with stereotypical forms of esthetics, often associated with holidays and leisure time activities in green spaces-traditionally, in rural sceneries associated with 'the countryside' or 'la campagne' (c.f. Aantrop and Van Eetvelde 2019). These stereotypical triggers may also refer to urban areas, with a specific focus on industrial innovations that increased the velocity of urban life (as the silver ball does in the game). Another characteristic category of pinball theme refers to (urban) games and gambling, which has an increased level of game intensity and ego-centeredness of the player. Two games can be won or lost at the same time. The landscape construct is usually concentrated on a local scale, including indoor spaces. Other categories of pinball themes are based on 'translatio ns' of popular media, (rock) music and space. These themes also fulfill the player's desire for escapism in different levels of intensity. If the spatial setting of a theme is known to the players (like in 'pinball interpretations' of movies, TV series or rock concerts), the emerging landscape constructs are not only influenced by individual and social (incl. cultural) factors and the accentuations of the pinball creator. They are also shaped by the original media the pinball themes refer to.

This article cannot cover all examples of pinball machines and their spatial storylines. It might have given an impression on the diversity and intensity (including immersion) the game offers to the players. It unites an unconventional and challenging approach to visualizing spatial stories with a (social) constructivist approach of landscape construction in games. In times of an increasing efficiency-driven cartography, pinball machines worshipped as vintage and retro games (see Rubens and Belofsky 2014)—include 'exotic' examples of spatial media. The successful story of the pinball industry, however, shows that generations of players have been fascinated by the spatial stories transported through map-like visualizations. If there is something like a 'pinballological cartography', it comprises arts, multisensory design, a high cognitive challenge, gamification of a spatial story and many triggers for the social and individual construction of landscapes, where players (map users) obviously enjoy spending their spare time. 
Acknowledgements Open Access funding provided by Projekt DEAL.

Open Access This article is licensed under a Creative Commons Attribution 4.0 International License, which permits use, sharing, adaptation, distribution and reproduction in any medium or format, as long as you give appropriate credit to the original author(s) and the source, provide a link to the Creative Commons licence, and indicate if changes were made. The images or other third party material in this article are included in the article's Creative Commons licence, unless indicated otherwise in a credit line to the material. If material is not included in the article's Creative Commons licence and your intended use is not permitted by statutory regulation or exceeds the permitted use, you will need to obtain permission directly from the copyright holder. To view a copy of this licence, visit http://creativecommons.org/licenses/by/4.0/.

\section{References}

Aantrop M, Van Eetvelde V (2019) Territory and/or scenery: concepts and prospects of western landscape research. In: Mueller L, Eulenstein F (eds) Current trends in landscape research. Springer, Cham, pp 3-39

Adams E (2014) Fundamentals of game design, 3rd edn. New Riders, Indianapolis

Ahlqvist O (2011) Converging themes in cartography and computer games. Cartogr Geogr Inf Sc 38(3):278-285. https://doi. org/10.1559/15230406382278

Barton M (2017) Vintage games 2.0. An insider look at the most influential games of all time. CRC Press, Boca Raton

Bendrups F (2004) The tango space of Argentina. In: King S, Browitt J (eds) The space of culture. Critical readings in hispanic studies. University of Delaware Press, Newark, pp 100-109

Berger M, Bill R (2019) Combining VR visualization and sonification for immersive exploration of urban noise standards. Multimodal Technol Interact 3(2):34. https://doi.org/10.3390/mti3020034

Boletsis C (2017) The new era of virtual reality locomotion: a systematic literature review of techniques and a proposed typology. Multimodal Technol Interact 1(4):24. https://doi.org/10.3390/ mti1040024

Brauen G, Taylor DRF (2008) Linked audio representation in cybercartography: guidance from animated and interactive cartography for using sound. Rev Bras Cartogr 60(3):223-242

Bueschel RM, Gronowski S (1993) Arcade 1: illustrated historical guide to arcade machines. Coin Slot Books, Wheat Ridge

Burgess J, Gold JR (1985) Geography, the media and popular culture. Croom Helm, London

Burgun K (2013) Game design theory. A new philosophy for understanding games. CRC Press, New York

Büyüksalih G, Kan T, Özkan GE, Meriç M, Isın L, Kersten TP (2020) Preserving the knowledge of the past through virtual visits: from 3D laser scanning to virtual reality visualisation at the Istanbul Çatalca İnceğiz Caves. PFG J Photogram Remote Sens Geoinf Sci. https://doi.org/10.1007/s41064-020-00091-3

Calleja G (2010) Digital games and escapism. Games Culture J Interact Media 5(4):335-353. https://doi.org/10.1177/1555412009 360412

Caquard S, Brauen G, Wright B, Jasen P (2008) Designing sound in cybercartography: from structured cinematic narratives to unpredictable sound/image interactions. Int J Geogr Inf Sci 22(1112):1219-1245. https://doi.org/10.1080/13658810801909649

Cartwright W (2007) Development of multimedia. In: Cartwright W, Peterson MP, Gartner G (eds) Multimedia cartography. Springer, Berlin, pp 11-34

Ciuffo S (2014) Pinball. Unigroove, Utrecht
Clarke KC, Johnson JM, Trainor T (2019) Contemporary American Cartographic Research: a review and prospective. Cartogr Geogr Inf Sc 46(3):196-209. https://doi.org/10.1080/15230 406.2019.1571441

Çöltekin A, Oprean D, Wallgrün JO, Klippel A (2019) Where are we now? Re-visiting the digital earth through human-centered virtual and augmented reality geovisualization environments. Int J Digit Earth 12(2):119-122. https://doi.org/10.1080/17538 947.2018.1560986

Cosgrove DE (1998) Introduction to the social formation and symbolic landscape. In: DeLue RZ, Elkins J (eds) Landscape theory. Routledge, London, pp 17-42

Coulton P, Huck J, Gradinar A, Salinas L (2017) Mapping the beach beneath the street: digital cartography for the playable city. In: Nijholt A (ed) Playable cities. The city as digital playground. Springer, Singapore, pp 137-162

de Almeida Pereira GH, Stock K, Stamato Delazari L, Centeno JAS (2017) Augmented reality and maps: new possibilities for engaging with geographic data. Cartogr J 54:313-321. https://doi. org/10.1080/00087041.2017.1411417

Dear MJ (2000) The postmodern urban condition. Blackwell, Oxford

Dickmann F, Edler D, Bestgen A-K, Kuchinke L (2017) Exploiting illusory grid lines for object-location memory performance in urban topographic maps. Cartogr J 54(3):242-253. https://doi. org/10.1080/00087041.2016.1236509

Dickmann F, Keil J, Kuner J, Edler D (2019) Quadratische Gitterzellen in Topographischen Karten erhöhen die Genauigkeit von Distanzschätzungen. KN J Cartogr Geogr Inf 69(2):109-120. https:// doi.org/10.1007/s42489-019-00014-2

Dong W, Yang T, Liao H, Meng L (2020) How does map use differ in virtual reality and desktop-based environments? Int J Digital Earth. https://doi.org/10.1080/17538947.2020.1731617

Dormann C, Caquard S, Woods BA, Biddle R (2006) Role-playing games in cybercartography: multiple perspectives and critical thinking. Cartogr Int J Geogr Inf Geovisual 41/1:47-58. https ://doi.org/10.3138/D781-R2Q5-5587-3153

Dunlap JC, Lowenthal PR (2016) Getting graphic about infographics: design lessons learned from popular infographics. J Vis Literacy 35(1):42-59. https://doi.org/10.1080/10511 44X.2016.1205832

Edler D, Dickmann F (2016) Interaktive Multimediakartographie in frühen Videospielwelten-Das Beispiel "Super Mario World". KN J Cartogra Geogr Inf 66/2:51-58. https://doi.org/10.1007/ BF03545205

Edler D, Dickmann F (2017) The impact of 1980s and 1990s video games on multimedia cartography. Cartogr Int J Geogr Inf Geovisual 52/2:168-177. https://doi.org/10.3138/cart.52.2.3823

Edler D, Kühne O (2019) Nicht-visuelle Landschaften. In: Kühne O, Weber F, Berr K, Jenal C (eds) Handbuch Landschaft. Springer VS, Wiesbaden, pp 599-612

Edler D, Vetter M (2019) The simplicity of modern audiovisual web cartography: an example with the open source javascript library leaflet.js. KN J Cartogr Geogr Inf 69/1:51-62. https:// doi.org/10.1007/s42489-019-00006-2

Edler D, Husar A, Keil J, Vetter M, Dickmann F (2018a) Virtual Reality (VR) and open source software: a workflow for constructing an interactive cartographic VR environment to explore urban landscapes. KN J Cartogr Geogr Inf 68/1:3-11. https://doi. org/10.1007/BF03545339

Edler D, Keil J, Dickmann F (2018b) Varianten interaktiver Karten in Video- und Computerspielen-Eine Übersicht. KN J Cartogr Geogr Inf 68(2):57-65. https://doi.org/10.1007/BF03544525

Edler D, Kühne O, Jenal C, Vetter M, Dickmann F (2018c) Potenziale der Raumvisualisierung in Virtual Reality (VR) für die sozialkonstruktivistische Landschaftsforschung. KN J Cartogr Geogr Inf 68(5):245-254. https://doi.org/10.1007/BF03545421 
Edler D, Keil J, Wiedenlübbert T, Sossna M, Kühne O, Dickmann F (2019a) Immersive VR experience of redeveloped post-industrial sites: the example of "Zeche Holland" in Bochum-Wattenscheid. KN J Cartogr Geogr Inf 69(4):267-284. https://doi.org/10.1007/ s42489-019-00030-2

Edler D, Kühne O, Keil J, Dickmann F (2019b) Audiovisual cartography: established and new multimedia approaches to represent soundscapes. KN J Cartogr Geogr Inf 69/1:5-17. https://doi. org/10.1007/s42489-019-00004-4

Eiden H, Lukas J (1992) Pinball machines. Schiffer Publishing Co, West Chester

Escher A, Zimmermann S (2001) Geography meets Hollywood. Die Rolle der Landschaft im Spielfilm. Geographische Zeitschrift 89/4:227-236

Evans A (2001) This virtual life. Escapism and simulation in our media world. Fusion Press, London

Flower G, Kurtz B (1988) Pinball: the lure of the silver ball. Book Sales, New York

Fontaine D (2017) Simulierte Landschaften in der Postmoderne. Reflexionen und Befunde zu Disneyland, Wolfersheim und GTA V. Springer VS, Wiesbaden

Fowlks RJ (2019) Autosave triggered. The Las Vegas pinball hall of fame. Retro Fan 6:75-77

Garfield S (2012) On the map. Why the world looks the way it does. Profile Books, London

Gemma (2013) Minecraft: creating a map of Great Britain. https:// www.ordnancesurvey.co.uk/blog/2013/09/minecraft-creating-amap-of-great-britain/. Accessed 10 Mar 2020

Ginns P (2006) Integrating information: a meta-analysis of the spatial contiguity and temporal contiguity effects. Learn Instruct 16(6):511-525. https://doi.org/10.1016/j.learninstr uc.2006.10.001

Griffin AL, Fabrikant SI (2012) More maps, more users, more devices means more cartographic challenges. Cartogr J 49(4):298-301. https://doi.org/10.1179/0008704112Z.00000000049

Harvey D (1990) The condition of postmodernity: an enquiry into the origins of cultural change. Blackwell, Oxford

Howard PJ (2011) An introduction to landscape. Ashgate, Farnham

Hruby F (2019) The sound of being there: audiovisual cartography with immersive virtual environments. KN J Cartogr Geogr Inf 69(1):19-28. https://doi.org/10.1007/s42489-019-00003-5

Hruby F, Ressl R, del Valle G (2019) Geovisualization with immersive virtual environments in theory and practice. Int J Digit Earth 12(2):123-136. https://doi.org/10.1080/17538947.2018.1501106

Indans R, Hauthal E, Burghardt D (2019) Towards an audio-locative mobile application for immersive storytelling. KN J Cartogr Geogr Inf 69(1):41-50. https://doi.org/10.1007/s42489-01900007-1

Jamei E, Mortimer M, Seyedmahmoudian M, Horan B, Stojcevski A (2017) Investigating the role of virtual reality in planning for sustainable smart cities. Sustainability 9(11):2006. https://doi. org/10.3390/su9112006

Jenal C (2019) (Alt)Industrielandschaften. In: Kühne O, Weber F, Berr K, Jenal C (eds) Handbuch Landschaften. Springer VS, Wiesbaden, pp 831-841

Juul J (2005) Games telling stories? In: Raessens J, Goldstein J (eds) Handbook of computer game studies. MIT Press, Cambridge, pp 219-226

Kapenekakis I, Chorianopoulos K (2017) Citizen science for pedestrian cartography: collection and moderation of walkable routes in cities through mobile gamification. Human-Centric Comput Inf Sci 7:10. https://doi.org/10.1186/s13673-017-0090-9

Keil J, Korte A, Ratmer A, Edler D, Dickmann F (2020) Augmented reality (AR) and spatial cognition: effects of holographic grids on distance estimation and location memory in a $3 \mathrm{D}$ indoor scenario. PFG J Photogram Remote Sens Geoinf Sci. https:// doi.org/10.1007/s41064-020-00104-1

Kent AJ (2013) Understanding aesthetics: the cartographers' response. Bull Soc Cartogr 46:31-43

Kent AJ (2018) Cartographic aesthetics. In: Kent AJ, Vujakovic P (eds) The Routledge handbook of mapping and cartography. Routledge, London, pp 299-310

Kersten T, Deggim S, Tschirschwitz F, Lindstaedt MU, Hinrichsen N (2018) Segeberg 1600—Eine Stadtrekonstruktion in virtual reality. KN J Cartogr Geogr Inf 68/4:183-191

Keskin M, Ooms K, Dogru AO, de Maeyer P (2019) EEG and eye tracking user experiments for spatial memory tasks on maps. ISPRS Int J Geo-Inf 8(12):546. https://doi.org/10.3390/ijgi8 120546

Krygier JB (1994) Sound and geographic visualization. In: MacEachren AM, Taylor DRF (eds) Visualization in modern cartography. Elsevier, Oxford, pp 149-166

Kuchinke L, Dickmann F, Edler D, Bordewieck M, Bestgen A-K (2016) The processing and integration of map elements during a recognition memory task is mirrored in eye-movement patterns. J Environ Psychol 47:213-222. https://doi.org/10.1016/j.jenvp 2016.07.002

Kühne O (2012) Landschaftstheorie und Landschaftspraxis: Eine Einführung aus sozialkonstruktivistischer Perspektive. Springer VS, Wiesbaden

Kühne O (2015) Weltanschauungen in regionalentwickelndem Handeln-Die Beispiele liberaler und konservativer Ideensysteme. In: Kühne O, Weber F (eds) Bausteine der Regionalentwicklung. Springer, Wiesbaden, pp 55-69

Kühne O (2017) Der intergenerationelle Wandel landschaftsästhetischer Vorstellungen. Eine Betrachtung aus sozialkonstruktivistischer Perspektive. In: Kühne O, Megerle H, Weber F (eds) Landschaftsästhektik und Landschaftswandel. Springer, Wiesbaden, pp 53-67

Kühne O (2018a) Landscape and power in geographical space as a social construct. Springer, Cham

Kühne O (2018b) Landschaft und Wandel. Zur Veränderlichkeit von Wahrnehmungen. Springer VS, Wiesbaden

Kühne O (2019) Landscape theories. A brief introduction. Springer VS, Wiesbaden

Kühne O, Schönwald A (2015) San Diego. Eigenlogiken, Widersprüche und Hybriditäten in und von, America's finest city ${ }^{\circ}$. Springer VS, Wiesbaden

Kurtz B (1994) Arcade treasures. Schiffer Publishing Ltd, Atglen

Laakso M, Sarjakoski LT (2010) Sonic maps for hiking-use of sound in enhancing the map use experience. Cartogr J 47(4):300-307. https://doi.org/10.1179/000870410X12911298276237

Lammert-Siepmann N, Bestgen A-K, Edler D, Kuchinke L, Dickmann F (2017) Audiovisual communication of object-names improves the spatial accuracy of recalled object-locations in topographic maps. PLoS ONE 12(10):e0186065. https://doi.org/10.1371/ journal.pone. 0186065

Lammes S (2008) Playing the world: computer games, cartography and spatial stories. Aether J Med Geogr 3:84-96. https://www.jurn. org/ejournal/lammes.pdf

Lanzinger F (2019) Classic game design. From Pong to Pac-Man with unity, 2nd edn. Mercury Learning \& Information, Boston

Lauriault TP, Taylor DRF (eds) (2014) Developments in the theory and practice of cybercartography. Applications and indigenous mapping, 2nd edn. Elsevier Science, Amsterdam

Liessmann KP (2009) Ästhetische Empfindungen. Eine Einführung Facultas, Wien

Lindner C, Rienow A, Jürgens C (2019) Augmented Reality applications as digital experiments for education-an example in the earth-moon system. Acta Astronaut 161:66-74. https://doi. org/10.1016/j.actaastro.2019.05.025 
Linke S (2019) Landschaftsästhetik. In: Kühne O, Weber F, Berr K, Jenal C (eds) Handbuch Landschaft. Springer VS, Wiesbaden, pp 441-452

Lokka IE, Çöltekin A, Wiener J, Fabrikant SI, Röcke C (2018) Virtual environments as memory training devices in navigational tasks for older adults. Sci Rep 8:10809. https://doi.org/10.1038/s4159 8-018-29029-x

Lovett A, Appleton K, Warren-Kretzschmar B, von Haaren C (2015) Using 3D visualization methods in landscape planning: an evaluation of options and practical issues. Landsc Urban Plan 142:8594. https://doi.org/10.1016/j.landurbplan.2015.02.021

Lukinbeal C (2005) Cinematic landscapes. J Cultural Geogr 23(1):322. https://doi.org/10.1080/08873630509478229

Lütjens M, Kersten T, Dorschel B, Tschirschwitz F (2019) Virtual reality in cartography: Immersive 3D visualization of the Arctic Clyde Inlet (Canada) using digital elevation models and Bathymetric data. Multimodal Technol Interact 3(1):9. https://doi. org $/ 10.3390 / \mathrm{mti} 3010009$

Lynch K (1960) The image of the city. MIT Press, Cambridge

Ma Y, Wright J, Gopal S, Phillips N (2020) Seeing the invisible: from imagined to virtual urban landscapes. Cities 98:102559. https:// doi.org/10.1016/j.cities.2019.102559

MacEachren AM (2004) How maps work. Representation, visualization, and design. Guilford Press, New York

Martella R, Kray C, Clementini E (2015) A gamification framework for volunteered geographic information. In: Proceedings of the international AGILE 2015 conference-geographic information science as an Enabler of Smarter Cities and Communities, Lisbon, Portugal, 9-12 June, pp 73-89

Meier S (2017) Visualisations in online news-and their effect on perceived credibility. KN J Cartogr Geogr Inf 67(2):74-83. https:// doi.org/10.1007/BF03545380

Micheel M (2012) Alltagsweltliche Konstruktionen von Kulturlandschaft. Raumforschung und Raumordnung 702:107-117. https ://doi.org/10.1007/s13147-011-0143-x

Morrison J (1974) A theoretical framework for cartographic generalisation with emphasis on the progress of symbolisation. Int Yearbook Cartogr 14:115-127

Müller J-C, Laurini R (1997) La cartographie de l'an 2000. Rev Int Géomatique 7(1):87-106

Muriel D, Crawford G (2018) Video games as culture: considering the role and importance of video games in contemporary society. Routledge, Abingdon

Nordheim A, Antoni K (2013) Grenzüberschreitungen. Der Mensch im Spannungsfeld von Biologie. Transcript, Bielefeld

Okabayashi H, Glynn SM (1984) Spatial cognition: systematic distortions in cognitive maps. J Gen Psychol 111(2):271-279. https:// doi.org/10.1080/00221309.1984.9921116

Postma A, De Haan EH (1996) What was where? Memory for object locations. Quart J Exp Psychol Sect A 49/1:178-199. https://doi. org/10.1080/713755605

Robinson AH (1952) The look of maps: an examination of cartographic design. University of Wisconsin Press, Madison

Rossignoli M (2003) Pinball memories. Forty years of fun. 1958-1998. Schiffer Publishing Ltd, Atglen

Rossignoli M (2011) The complete pinball book. Collecting the game and its history, 3rd edn. Schiffer Publishing Ltd, Atglen

Rossignoli M, McGuiness G (2007) Pinball perspectives: ace high to world's series. Schiffer Publishing Ltd, Atglen

Roth R, Çöltekin A, Delazari L, Fonseca Filho H, Griffin A, Hall A et al (2017) User studies in cartography: opportunities for empirical research on interactive maps and visualizations. Int J Cartogr 3(1):61-89. https://doi.org/10.1080/23729333.2017.1288534

Rubens P, Belofsky R (2014) The silent art of vintage pinball. An interview with pinball photographer Santiago Ciuffo. In: Joosten J (ed) Pinball magazine, pp 9-14
Salter JD, Campbell C, Journeay M, Sheppard SRJ (2009) The digital workshop: exploring the use of interactive and immersive visualisation tools in participatory planning. J Environ Manage 90(6):2090-2101. https://doi.org/10.1016/j.jenvman.2007.08.023

Schafer RM (1977) The soundscape. Our sonic environment and the tuning of the world. Destiny Books, Rochester

Schiewe J (2017) Journalistic cartography—setting the research agenda. KN J Cartogr Geogr Inf 66/5:245-253. https://doi. org/10.1007/BF03545319

Schiewe J (2019) Empirical studies on the visual perception of spatial patterns in choropleth maps. KN J Cartogr Geogr Inf 69/3:217228. https://doi.org/10.1007/s42489-019-00026-y

Schito J, Fabrikant SI (2018) Exploring maps by sound: using parameter mapping sonification to make digital elevation models audible. Int J Geogr Inf Sci 32(5):874-906. https://doi. org/10.1080/13658816.2017.1420192

Schönwald A (2015) Die Transformation von Altindustrielandschaften. In: Kühne O, Gawronski K, Hernik J (eds) Transformation und Landschaft, Die Folgen sozialer Wandlungsprozesse auf Landschaft. Springer VS, Wiesbaden, pp 63-73

Shalhoub M (2002) The pinball compendium. 1930s-1960s. Schiffer Publishing Ltd, Atglen

Shalhoub M (2004) The pinball compendium. 1970-1981. Schiffer Publishing Ltd, Atglen

Shalhoub M (2005) The pinball compendium. 1982 to present. Schiffer Publishing Ltd, Atglen

Shalhoub M (2012) The pinball compendium. 1982 to present, 2nd edn. Schiffer Publishing Ltd, Atglen

Sharpe RC (1977) Pinball!. Dutton, New York

Stevens A, Coupe P (1978) Distortions in judged spatial relations. Cogn Psychol 10(4):422-437. https://doi.org/10.1016/00100285(78)90006-3

Stoff J (2008) Images of aviation. LaGuardia Airport. Arcadia Publishing, Charleston

Taylor DRF (ed) (2006) Cybercartography: theory and practice. Elsevier Science, Amsterdam

Taylor DRF, Lauriault TP (2007) Future directions for multimedia cartography. In: Cartwright W, Peterson MP, Gartner G (eds) Multimedia cartography. Springer, Berlin, pp 505-522

Tschirschwitz F, Richerzhagen C, Przybilla H-J, Kersten T (2019) Duisburg 1566: transferring a historic 3D city model from Google Earth into a virtual reality application. PFG J Photogram Remote Sens Geoinf Sci 87/1-2:47-56. https://doi.org/10.1007/ s41064-019-00065-0

Tversky B (1981) Distortions in memory for maps. Cogn Psychol 13(3):407-433. https://doi.org/10.1016/0010-0285(81)90016-5

Vetter M (2019) 3D-Visualisierung von Landschaft-Ein Ausblick auf zukünftige Entwicklungen. In: Kühne O, Weber F, Berr K, Jenal C (eds) Handbuch Landschaft. Springer VS, Wiesbaden, pp 559-573

Virtanen JH, Hyyppä H, Kämäräinen A, Hollström T, Vastaranta M, Hyyppä $\mathbf{J}$ (2015) Intelligent open data 3D maps in a collaborative virtual world. ISPRS J Geo Inf 4(2):837-857. https://doi. org/10.3390/ijgi4020837

Walmsley A, Kersten TP (2020) The Imperial Cathedral in Königslutter (Germany) as an immersive experience in virtual reality with integrated $360^{\circ}$ panoramic photography. Appl Sci 10(4):1517. https://doi.org/10.3390/app10041517

Werner P (2019) Review of implementation of augmented reality into the georeferenced analogue and digital maps and images. Information 10(1):12. https://doi.org/10.3390/info10010012

Whyte ID (2002) Landscape and history since 1500. Reaktion Books, London

Wolf MJP (2014) Worlds. In: Wolf MJP, Perron B (eds) The Routledge companion to video game studies. Routledge, New York, pp 125-131 
Zhao J, Wallgrün JO, LaFemina PC, Normandeau J, Klippel A (2019) Harnessing the power of immersive virtual reality-visualization and analysis of 3D earth science data sets. Geo-spatial Inf Sci. https://doi.org/10.1080/10095020.2019.1621544

Zimmermann S (2019) Filmlandschaft. In: Kühne O, Weber F, Berr K, Jenal C (eds) Handbuch Landschaft. Springer VS, Wiesbaden, pp 623-629

Zook M, Poorthuis A, Donohue R (2017) Mapping spaces: cartographic representations of online data. In: Fielding NG, Lee RM, Blank G (eds) The SAGE handbook of online research methods, 2nd edn. SAGE, London, pp 542-560

Zsolnay P (1994) Pinball. Cartwell Books, London 